\begin{tabular}{c} 
Volume and Issues Obtainable at Center for Sustainability Research and Consultancy \\
Responsible Education, Learning and Teaching in Emerging Economies \\
ISSN: $2708-4310$ \& (E): 2708-4183 \\
Volume 2: No.2, December 2020 \\
CSRᄃ \\
Jofit \\
\hline
\end{tabular}

\title{
Importance of Philosophical Framework of Education on Social and Economic System of the Developing Nations
}

*Rahat Sabah, PhD Scholar, Greenwich University Karachi, Pakistan

*Corresponding Author's email: Rahatsabah@ gmail.com

\begin{tabular}{l}
\hline ARTICLE DETAILS \\
\hline History \\
Revised format: Nov 2020 \\
Available Online: Dec 2020
\end{tabular}

Keywords

Scientific Research

Philosophies, Research

Paradigms, Education

System, Higher Degree

Research Student

JEL Classification

A2, A23

\begin{abstract}
Purpose: The aim of this paper is to highlight the importance of Philosophical System of Education in the developing regions. This study emphasized on significance of learning of Scientific Research philosophies and paradigms to generate new ideas in business, education \& research to meet the challenges faced by developing and growing economies.
\end{abstract}

Methodology: This paper reviews the various theories, philosophies and, paradigm briefly to explore that how, effect of paradigms on the methodologies of research from selection of research topic to data analysis.

Findings: The study has found that a theoretical direction of a researcher is very important in producing a creative knowledge. To improve the learning process, education, business and technical schooling and research process there is need to explore this area further.

Implications: To improve education system extensive research in this area required. This system will work as an intellectual tool that provide us meaningful path towards financial and social life. Therefore, researchers should learn from previous studies to conduct further research on Educational philosophical system.

(C) 2020 The authors, under a Creative Commons AttributionNonCommercial 4.0

Recommended citation: Sabah, R.(2020) Importance of Philosophical Educational Framework on Social and Economic System of the Developing Nations. Responsible Education, Learning and Teaching in Emerging Economies, 2 (2), 65-74.

\section{Introduction}

Developing nations are doing efforts to make batter their place or world, in which they live. During the exploration of the answer a question of how could emerging countries be able to improve their social and financial health? And why scientific research philosophy and paradigm are important to develop a research proposal? I found that the philosophy is not the part of an education it is the origin knowledge of business, science and mathematics, all kinds of knowledge on earth. Philosophical education system could provide the solution of all kinds of problems or resolves the issue faced to mankind. The word Philosophy mean "love of knowledge" (Jassem, 2016). The process of Education provides the, skills, standards learning, training discussion and research. Education system becomes complete or possible under the help of teachers (Winch, 2015). Masters, (2003) has definited that the Research is an advance level of education. It is the 
way of finding information about problems, it is a point of an outlook and description of a work to plan and come to a decision. Similarly Awang, (2012) stated that there is no research, if there is no problem. Research process is start when a student asked to undertake a research to fulfill the requirement of graduate degree or writing a statement for Master and $\mathrm{PhD}$ thesis. At the beginning, it feels like at the sea, surprising and wondering, what is expected and how to the deal with. The person who starts research work first time, he has to face worries and anxiety a lot Blaxter, (2010).

Although this time a wide-ranging awareness has been created about the significance of $R \& D$,its financial impact are keenly discussed among scholars as the knowledge, strategic planning, governmental development, information, technology, legal trade, industry and globalization's point of view. Modern researches, as well as articles on special issues is creating innovative concepts which show that how, R\&D is important and could add value in learning process (Enkel et al., 2009)). There is always be need of new emerging and creative methods of R\&D. No doubt the review of scholarly manuscripts or literature give useful information about, what need to be learn and how it should be learn (Foss \& Saebi, 2017).Different source of literature reviews, like primary sources, report new/original research and secondary sources provide you a general idea of previous research. Which enable you to develop specific questions of different types and not only could summarize your results in narrative or quantitative form but make you able to think about, which specific research approach, is suitable to answer the research questions Martinez(Noya \& Narula,2018)

The word meaning of Paradigm is a "Philosophical Way of Thinking". A research Paradigm basically is a represent the beliefs or idea of the authors about their surrounding and the world where they live or would like to live. Paradigm helps us to establish the intellectual belief and set of standards, that form how a scholar understand the world and how that researcher or scholar takes act within this world (Johnson, 2004). When it is said that the researcher's point of view it means, that a paradigms (standard, principle) set by you (as a researcher) for yourself to look, to live and act within this world (Mackenzie \& Knipe, 2006). Similarly the Perry\& Brown, (1999) has called the paradigm is a conceptual mirror through which you find the problem, observe the methodological aspect to define the methods that have used and analyzed your data in your research project. In addition Guba \& Lincoln, (1994) sated that because the paradigm are used in education to explain a philosopher or researchers' point of view, idea and way of thinking. So it becomes very important to provide you vision and instruction, about what should we study and how to study as well as guide we to analysis the outcome of research work. Furthermore paradigm play an imperative job in explaining our experience and hypnotizing the meaning collected from the research data (Kivunja \& Kuyini, 2017).

The contemporary philosophy of education is the most debated topic in foreign research. The ethical and political aims of education are discussed along with the professional status of the teachers. Ethical objectives of education means that a nation has the capability to live a full economic and social life. The nation has the ability to maintain personal development, democratic know-hows and have corporate skills. These ethical objectives of the education are closely connected provider's objectives, those who distributing the teaching efforts. Therefore the activities of professional should be discussed and analysis to set the slandered of professionalization (Salihu, 2017).

\section{Elements of a Paradigm/view point}

The paradigms are comprised into four elements, that is, ontology, methodology, epistemology, and axiology. These elements are very important to understand because they consist on fundamental beliefs, assumptions, standards and norm which every paradigm hold (Žukauskas et al., 2018). 


\section{Epistemology}

Epistemology is the part of philosophy which deals with knowledge; the episteme is Greek word, which means knowledge. When we used it in research it tells us the way of finding the facts, actuality and realities as well as sense of knowledge (Cunningham \& Fitzgerald, 1996). There is a powerful link between the Epistemology and knowledge. It related with the very base of knowledge which Include how you acquired this knowledge, what is the nature and form of this knowledge. In this beliefs the main focus and emphasize is given on the humans and their understanding about they have acquire as a researcher and philosophers. Knowledge is something which can be learns by one person and something which you have to be personally experienced. If a researcher take the factual information as truth, than this epistemology help him to ask the factual questions you count as knowledge? The research work of higher degree students is mostly evaluated and judged through this question of what is the source of contribution of your knowledge. The scholars or researchers have to provide the answer of the above question by stating the fallowing surceases of knowledge (Kinsella, 2010).

\begin{tabular}{|r|l|l|}
\hline S.No & \multicolumn{2}{|c|}{ Source of knowledge } \\
\hline - & Intuitive knowledge: & $\begin{array}{l}\text { Is created on the beliefs and emotional feeling rather than on } \\
\text { exact learning. Is based on individual judgement.(initial idea) }\end{array}$ \\
\hline - & Authoritative knowledge: & $\begin{array}{l}\text { Is acquire from the people, books, its strength is based on the } \\
\text { strength of its sources: (reviewing the literature) }\end{array}$ \\
\hline - & Empirical knowledge: & $\begin{array}{l}\text { This knowledge is come from intuitive knowledge and } \\
\text { accepted by authoritative knowledge.(thinking from finding to } \\
\text { concluding }\end{array}$ \\
\hline
\end{tabular}

\section{Ontology}

Source: (Davidson,2000)

Ontology deal with assumptions and belief made by a researcher or scholars about some things is real or natural, in other word the social phenomena which is going to be investigate. So we can say that, this is study of how some is exist or living? What is its natural history, its types and its relation with other living or things? This branch of philosophy help the researchers to hypothesize the arrangement and nature of reality and their beliefs, they know about reality. These truth-seeking hypotheses about the nature of the reality are very important and essential to understand for researchers to give meaning to the collected information and data. Furthermore it assists to adjust your thinking about the problem. So ontology is become important because it provide help to understand the things which constitute our world (Scotland, 2012).

\section{Methodology}

Methodology is part logic or philosophy which states the reason of something and the way through those things are done. It is widely used in process of research to identify, choose, process and justify or analyses the facts about an issue or matter. In other word methodology is the way through which an experiment is made to assess the strength and trustworthiness of the study (Williamson, 2008). The methods are the tools to perform research used by scholars and researchers, these tools are described as the experiment has done through an interview by collecting qualitative statistics or data. Obtaining of data, participants, analysis of data and instruments that you used in your research are the part of the field of the methodology. In addition the methodology is articulate and clear the flow and logic of your systematic research which you are going to conduct for your research project to acquire or gain knowledge about your research problem (Keeves, 1990). 


\section{Axiology}

Axiology deal with the ethical issues which we need to considered during a research planning for our research proposal. This philosophical approach is used to understand the right directions and to make decision of values. It is the study of the character, category and principle of the values. It guides us towards the ethics, religion, reality, right \& wrong and moral issues that we should measured (Viega, 2016). In the research Axiology will answer the question of what slandered you have set to do your study? What has done to show respect to your contributor's right.? How will you do you research within society unbiased, respectful and in peaceful way? How will you avoided or minimize the risk or hurt, no matter it be a mental, psychological, physical, lawful, social, financial or other. Responses to these queries or questions you will guided in a batter way through the four criteria of moral conduct these are the teleology (is the theory morality it tells us what is good and admirable while in a research process it means that weather you're is meaningful or not and weather its results would satisfy as much people as possible.) Deontology (is the understanding about the actions taken in your research, it tell us that every action would have its results including its own benefits regarding participant, public or your community) (Kivunja \& Kuyini, 2017).

Oliver, (2010) state that the ethics are the moral principles that should be maintained during the research process and fairness is the principle of justice that guides a researcher to word parity thought the research. To Implement he such criterion is directed by a questions like, how unbiased will your research actions be there? Will you treat every research participant's equally. Philosophy is love of knowledge and wisdom. This is actually a rational critical thinking in a some or more systematic way about the over-all nature of our world.So Feldman, (2000) also wrote in the defense of belief which is called epistemology / theory of knowledge, and the other are the conduct of life is called the theory of values. Everyone among of us has some common idea of the nature of our world in which we live or want to live. Metaphysics similarly. Every person has the opportunity to doubt and question about beliefs, his/her own or about of others, The Epistemology search for such argument through which it to make clear the directions of correct belief and its formation. Each person is governed and directed by his/her own conducted desired and valued. Therefore Ethics/ moral philosophy are seeking in its most comprehensive sense to express the logically systematic form, procedures and principles to live (Feldman, 2000).

\section{Philosophy of Research}

Huff \& Reger, (1987) has stated that the research is a going process. it feels like at the sea, surprising and wondering, what is expected and how to the deal with In education setting the Research procedure is initiate when a higher degree student asked to prepare a proposal for final assessment to get degree. The person who starts research work first time, he has to face worries and anxiety a lot (Blaxter, 2010) for such situation a student or researcher should ignore the time limit and gain a pepper knowledge and skills of how to research. No doubt the research is like a sea but we must know and learn of how to swim(Sarason, 1977) research is the way of finding the information about a an issue or problems, it is your point of view, and this is an outlook or description of a work plan and decision (Huff \& Reger,1987), while the analysis of data is a further process of applying the statistical and logical technique in a systematic way, so that a researcher could described or show his/her findings from collected data or information( Savenye \& Robinson,2005). No doubt at this time a wide-ranging awareness has been created about the significance of R\&D. The financial impact of $R \& D$ is discussed among scholars as well as articles on special issues are creating innovative concepts which give us an idea about that how, R\&D is important and could add value in learning process. There is always be need of new emerging and creative methods of R\&D (Enkel\& Chesbrough, 2009). Certainly the review of scholarly manuscripts or literature give useful information about, what need to be learn and how it should be learn. Which enable you to develop specific questions of different types and not only could summarize your results in narrative or quantitative form but make you able to think about, 
which specific research approach, is suitable to answer the research questions(Crossan,2003).Many students do not care in learning and understanding the research philosophy and its application. This seemed to be a some kind of dilemma towards research. If students do not learn research methods and paradigms, could not leave any impact on the new generation (Mackenzie \& Knipe, 2006).A research philosophy is supposed the way in which data about phenomena is collected, analyzed and used by scholars. We can say it is a method which allows you as a scholar to produce thoughts and ideas in current knowledge in the framework of study (Crossan, 2003). Four key trends are described in different schoolwork as:

- Positivist.

- Interpretive

- Pragmatist.

- Realistic (Žukauskas et al, .2018)).

Positivist Research Philosophy: This standard believe that real understanding could be achieved through observation and conducting tests. The Positivist philosophy is typically using a rational approach to produce information and recognized as a quantitative learning, scientific method and experimental analysis. In the positivism research philosophy, the reality is remains constant which can be observed and represented through an objective (Crossan, 2003).

Interpretive Research Philosophy: This principle is opposite of positivist viewpoint and believed that the subjective analysis of a researcher is important. It is created on the base of identification and understanding the viewpoint of research topic. Mostly begin with hypotheses and based on the researchers' own interest but realistic results are considered and measured in this research philosophy.

Pragmatist Research Philosophy: It deals with the evidences, it is generally standardize by research problem. The results generated from it are considered important. The Pragmatism research philosophy seemed to be not associated any philosophy system and realism .It is free from selecting methods, techniques and process .it has done on the basis of research aim and need of research. Its objectives are to identify the weak point in a research and try to make strengthen this weakness through mixed-method approach (Morgan, 2014).

Realistic Research philosophy: This philosophy is support the main beliefs of both positivist and interpretive research philosophies. It based on theory that is essential for the observation of subjective nature of humankind (Juma'h, 2006).

\section{Research Paradigms used in Educational Research?}

Many paradigms are applied by the researchers in the academic research but the three most dominant paradigms in educational field are the positivists, critical and interpretivists paradigms On the other hand the, some researcher a proposed fourth paradigms which is "Positivists" that barrow the elements from the other three paradigms (Kivunja \& Kuyini, 2017). Positivists Paradigm describes a worldview to study, which ideal with research techniques is called the scientific methods of research. In its true form, the scientific techniques/methods, are comprises a process of investigation which is applied to find out observations and response to a questions. This is used for find the nature of cause and effect of relationship of variables or phenomena .It is selected as an ideal paradigm or worldview for research (Park et al., 2020). Interpretivist Paradigm is opposite to the positivists views and directed by the scholar's beliefs and the feeling regarding the Word and way of understanding and studding. In this point of view knowledge is linked to a specific situations or setting that may be historical, cultural, and time-based and may have several form to represent the reality. It focus on the identifying and stating the experience or understanding and actions of human (Alharahsheh \& Pius,2020).Critical Paradigms also called Transformative Paradigm because, it locates the issues regarding social justice and seek to 
discuss social, economic and political issues to improve the social justice. In this viewpoint the author works together with the participants (Romm, 2015).

Pragmatic Paradigm The most scholars searched for appropriate methods which could provide them practical and diverse help them, which could provide them combination of approaches to high light the actual behavior of participant. Paradigmatic Paradigm supporters a relational epistemology. It also support with mixed approaches methodology like combination of qualitative and quantitative research techniques and axiology, which mean your research would provide benefits to general public. This Paradigm rose among those theorists who claimed that it is impossible to discover the truth about any reality and world with the help of a single scientific technique (Johnson \&Onwuegbuzie, 2004).

\section{Branches of Philosophy}

Akinsanya (2006) has evaluated the Philosophical branches are that are based on different group of questions these groups help the philosophers to focus on the same set of topics and they could work together other theorists who keep interest in the same questions. All knowledges, Information, facts are belong to philosophy. It has the answers of all questions from creating wealth, maintain Health, acquiring status (respect), bring peace (defense), politics (Pawer) and Learning/finding of facts.

\section{Branches of Education Philosophy}

Tesar \& Locke, (1973) described that the philosophy is the study to search the fact, truth and reality. It make effort to know the unseen realities truths about our surrounding and ourselves. Today in as an academic since the students of Philosophy programs are involved in a searching, asking, answering, and solving problems. In a sense, Philosophy is not a type of science, Philosophy is the basic of science .science is also branch of philosophy the main branches of education philosophy are the following.

The above group of thinkers are active

- Philosophy of creating wealth (Adams, 1886)

- Philosophy of Management Sciences (Rendtorff, 2013)

- Philosophy of health Sciences (Greenland, 2006).

- Philosophy of finding Facts (Frost, 1931)

\section{Research Types}

Carnevalli \& Miguel, (2008). Has described that the research is way of finding or solution of particular problem or seeking the knowledge through an investigation. We collected information from several sources. A new research can add value in the existing knowledge. The research is categorized in different types according to its viewpoint as listed below.

According to the Application of Research :( Basic Research, Applied Research) According to the Aim of Research :( Descriptive Research, Explanatory Research, Analytical Research)

According to the Mode of Research (Quantitative Research, Qualitative Research)

According to the aim of research approach :( Longitudinal Research, Crosses Sectional Research, Conceptual Research, Empirical Research)

Paradigm are help us to describe the research philosophy. The scientific Works or literature demanded that every researcher must learn the perfect vision of paradigms that develop our active understanding regarding philosophical, logical, theoretical, and procedural systems. (Anderson \& Shattuck,2012). 
$>$ Research Methodologies Well-matched with Positivist Paradigm: The Survey research policy is the mainly used methodology in this paradigm. (Žukauskas, \& Andriukaitienè, 2018).

$>$ Research Methodologies Well-matched to the Interpretivist Paradigm: Methodology of The Narrative inquiry ,The Naturalist ,, The Case study ,The Grounded theory, Action research methodology and o Heuristic inquiry are the main methodology which are well matched with this paradigm.

> Research Methodologies Well-matched to the Critical Paradigm: The Cultural studies. Feminist are the well know theories in this paradigm among others.

$>$ Research Methodologies Well-matched to the Pragmatic Paradigm: The Case study, and Action Research are the typically used in this paradigm (Dammak, 2015).

Because the research is the higher level of education that help to bring growth and advancement regarding in the life human beings. To continue or doing the process of research in a organized way, different methods are used to complete the task. Every method has its own level and strength. These methods tell us that how our results are authenticate ad accurate (Bogdan \& Biklen, 1997).On the other hand the methodology is not a research systems, rather it is our strategic style to do research and to find out or produce some knowledge and paradigm are the theories, through which we set the path to do resrch work (Dammak, 2015).

\section{Recommendation:}

1. The academic community who is the responsible of Management of education and social need should revised their education policies not only according the social and economic need of society but shape the style of thinking of the all students regardless of their time of study, their subject and their faculty also.

2. Philosophical framework of education will boost the intellectual belief of students and help them to set standards to understand the world and the problems in the world.

3. The education leaders have the responsibility to create philosophical Learning and teaching system, where the students could discuss the challenges faced to their communities to solve and to takes act within this world. The Leaders of education from the developing countries should come on a board to improve the education system according to actual wisdom.

4. No doubt the today's advance setting of global village that we are enjoying are due to philosophical knowledge. But there is need to seek more sophisticated ways to teach the philosophical education to new generation. These can be it can be provided by developing social media tools, school of R\&D learning, collages of innovation, and Special issues campaign for all level of students and thinkers.

5. There should be system of job rotation between the management of organizations and the teachers of the universities .in such a way a professor should give his/her duty in any organization for three month as director or CEO. With same the director or CEO of an organization will teach the student for three month also? In this this the CEO or director of the department not only could transfer his/her experience to students but share the challenges and issue faced to that organization also. On the other side the Teacher of a university during his/her three month period would the teach the management how to solve the problems. Help to enhance the performance of the organization. 
Figure: 1

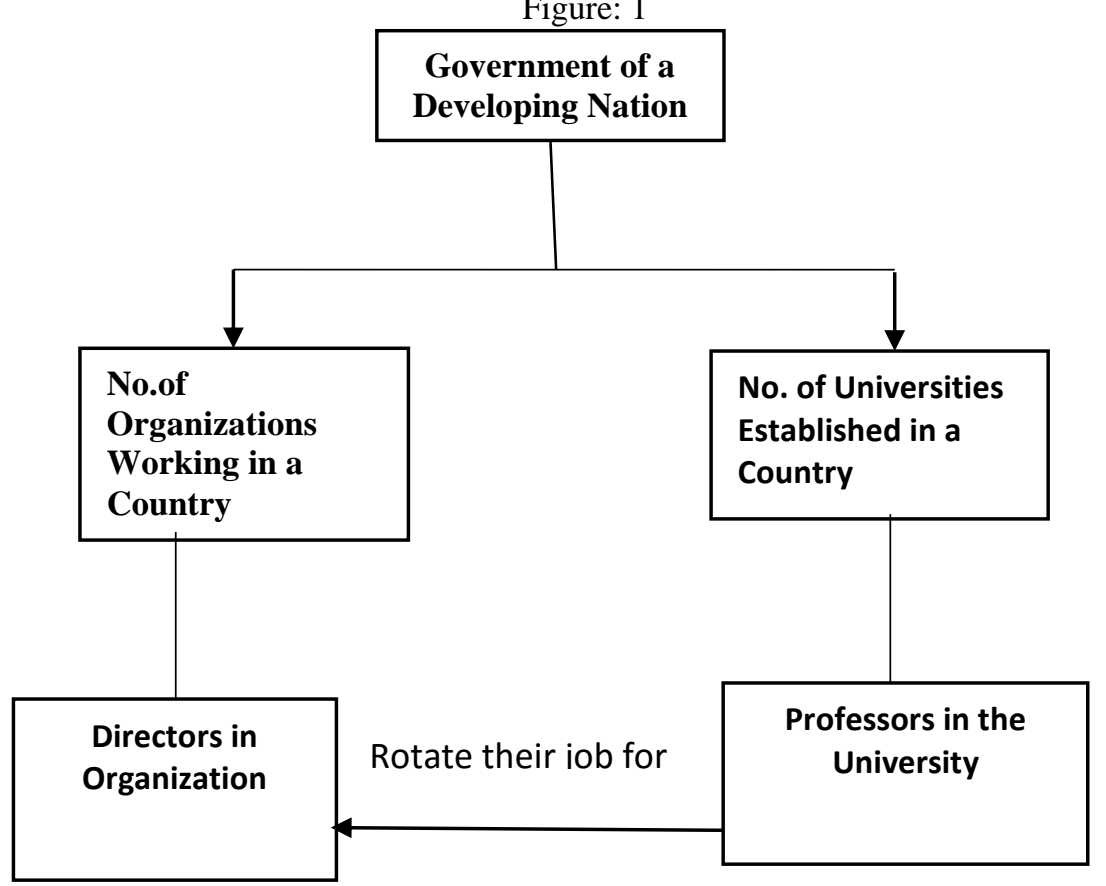

Figure.2

Financinal , Social \& Ethical Objectives of a Nation

\begin{tabular}{|c|c|c|}
\hline \multicolumn{3}{|c|}{ List of Government Corporations/Departments } \\
\hline \multicolumn{3}{|c|}{ Establish Universites and olleges with same name of Government Depatmer } \\
\hline \multicolumn{3}{|c|}{ Teach Philosophy of Each Subject } \\
\hline \begin{tabular}{l} 
National Schools system \\
of \\
Defence \\
Commerce \\
Finance \\
Trade \\
Anti-Corruption \\
Science \\
Technology \\
Languages \\
Management \\
Justice \\
Law Agricultural \\
Industry \\
Resources Management \\
$\quad$ All............other \\
\multicolumn{1}{c}{-}
\end{tabular} & $\begin{array}{l}\text { Provide } \\
\text { Services }\end{array}$ & $\begin{array}{l}\text { National } \\
\text { Departments/Ministries } \\
\text { of } \\
\text { Defence } \\
\text { Commerce } \\
\text { Finance } \\
\text { Trade } \\
\text { Anti-Corruption } \\
\text { Science } \\
\text { Technology } \\
\text { Languages } \\
\text { Management } \\
\text { Justice } \\
\text { Law } \\
\text { Agricultural } \\
\text { Industry } \\
\text { Resources } \\
\text { Management } \\
\text { All............other }\end{array}$ \\
\hline
\end{tabular}


The authorities of developing nations should increase the numbers of educational institutions in their region. Education institution should not less than the number of government department, because all department have their own function and different nature of work. Many department need to be updated according to the present age. So if the educational institution provide the education and skills according to their need than process of economic and social development automatically start running smoothly. Every Nation has its own objective. They should be teach their new generation through the philosophical of education system, in other word to change the thinking style from non- philosophical to philosophical way to meet these objectives in wright way, because the nation who adopt fast tracks by using unethical ways to gain power and progress could

not survive long in this world.

There is need to revise the system of education from the playgroup to Higher degree Research students and teach the philosophy of business, the philosophy of crating wealth, philosophy of philosophy of management, philosophy of medical sciences \& social sciences. Which would help the students boost their power of thinking and understanding of things present in this universe. We human have the power to use the all possessions of the world as we like. Such philosophical education system not only would provide us the guidance about how to use these resources but help us to right ways to use them also.

\section{References}

Awang, Z. (2012). Research methodology and data analysis second edition. UiTM Press. Adams, H. C. (1886). The Philosophy of Wealth.

Alharahsheh, H. H., \& Pius, A. (2020). A review of key paradigms: Positivism VS interpretivist. Global Academic Journal of Humanities and Social Sciences, 2(3), 3943.Akinsanya, P. O. (2006). Branches of Philosophy. Hope Publications Limited.

Anderson, T., \& Shattuck, J. (2012). Design-based research: A decade of progress in education research?. Educational researcher, 41(1), 16-25.

Adler, Mortimer J. (2000). How to Think About the Great Ideas: From the Great Books of Western Civilization. Chicago, Ill.: Open Court. ISBN 978-0-8126-9412-3.

Blaxter, L. (2010). How to research. McGraw-Hill Education (UK)

Bogdan, R., \& Biklen, S. K. (1997). Qualitative research for education. Boston, MA: Allyn \& Bacon

Crossan, F. (2003). Research philosophy: towards an understanding. Nurse Researcher (through 2013), 11(1), 46

Carnevalli, J. A., \& Miguel, P. C. (2008). Review, analysis and classification of the literature on QFD-Types of research, difficulties and benefits. International Journal of Production Economics, 114(2), 737-754.

Cunningham, J. W., \& Fitzgerald, J. (1996). Epistemology and reading. Reading research quarterly, 31(1), 36-60.

Davidson, R. J. (2000). Affective style, psychopathology, and resilience: brain mechanisms and plasticity. American Psychologist, 55(11), 1196.

Dammak, A. (2015). Research paradigms: Methodologies and compatible methods. Veritas, 6(2), $1-5$.

Enkel, E., Gassmann, O., \& Chesbrough, H. (2009). Open R\&D and open innovation: exploring the phenomenon. R\&D Management, 39(4), 311-316

Foss, N. J., \& Saebi, T. (2017). Fifteen years of research on business model innovation: How far have we come, and where should we go?. Journal of Management, 43(1), 200-227.

Feldman, R. (2000). The ethics of belief. Philosophy and Phenomenological Research, 60(3), 667-695

Frost, S. E. (1931). A Philosophy of Facts. The Phi Delta Kappan, 14(3), 87-89. 
Guba, E. G., \& Lincoln, Y. S. (1994). Competing paradigms in qualitative

Greenland, S. (2006). Smoothing observational data: a philosophy and implementation for the health sciences. International statistical review, 74(1), 31-46.

Huff, A. S., \& Reger, R. K. (1987). A review of strategic process research. Journal of management, 13(2), 211-236.

Johnson, R. B., \& Onwuegbuzie, A. J. (2004). Mixed methods research: A research paradigm whose time has come. Educational researcher, 33(7), 14-26

Jassem, Z. A. Harper's (2016) Online Etymology Dictionary (Etymonline): A Critical Review.

Kinsella, E. A. (2010). Professional knowledge and the epistemology of reflective practice. Nursing philosophy, 11(1), 3-14.

Kivunja, C., \& Kuyini, A. B. (2017). Understanding and applying research paradigms in educational contexts. International Journal of higher education, 6(5), 26-41

Keeves, J. P. (1990). Educational research, methodology, and measurement: An international handbook. Pergamon Press

Masters, G. N. (2003). Using research to advance professional practice.

Martinez-Noya, A., \& Narula, R. (2018). What more can we learn from R\&D alliances? A review and research agenda. BRQ Business Research Quarterly, 21(3), 195-212.

Mackenzie, N., \& Knipe, S. (2006). Research dilemmas: Paradigms, methods and methodology. Issues in educational research, 16(2), 193-205.

Morgan, D. L. (2014). Pragmatism as a paradigm for social research. Qualitative inquiry, 20(8), 1045-1053.

Oliver, P. (2010). The student's guide to research ethics. McGraw-Hill Education (UK).

Perry, C., Riege, A., \& Brown, L. (1999). Realism's role among scientific paradigms in marketing research. Irish Marketing Review, 12(2), 16-23.

Romm, N. R. (2015). Reviewing the transformative paradigm: A critical systemic and relational (Indigenous) lens. Systemic Practice and Action Research, 28(5), 411-427.

Rendtorff, J. D. (2013). Basic concepts of philosophy of management and corporations. Handbook of the philosophical foundations of business ethics, 1361-1386.

R.B. Johnson and A.J. Onwuegbuzie. "Mixed methods research: A research paradigm whose time has come." Educational researcher, Vol 33,pp. 14-26, 2004

Salihu, M. J. (2017). Qualitative and quantitative debates in contemporary educational research. International journal of Research, 7(5).

Scotland, J. (2012). Exploring the philosophical underpinnings of research: Relating ontology and epistemology to the methodology and methods of the scientific, interpretive, and critical research paradigms. English language teaching, 5(9), 9-16.

Savenye, W. C., \& Robinson, R. S. (2005). Using qualitative research methods in higher education. Journal of computing in Higher education

Sarason, I. G. (1977). The test anxiety scale: Concept and research.,

Tesar, M., \& Locke, K. (1973). The philosophy of education (pp. 2-4). R. S. Peters (Ed.). Oxford: Oxford University Press.

Viega, M. (2016). Science as art: Axiology as a central component in methodology and evaluation of arts-based research (ABR). Music Therapy Perspectives, 34(1), 4-13

Winch, P. (2015). The idea of a social science and its relation to philosophy. Routledge

Williamson, T. (2008). The philosophy of philosophy. John Wiley \& Sons.

Žukauskas, P., Vveinhardt, J., \& Andriukaitienè, R. (2018). Philosophy and paradigm of scientific research. Management Culture and Corporate Social Responsibility, 121. 